\title{
LONGING FOR HOME
}


This page intentionally left blank 


\section{JAN HOLTON}

\section{Longing for Home}

Forced Displacement and

Postures of Hospitality

Yale University PRESS NEW HAVEN AND LONDON 
Copyright $@ 2016$ by M. Jan Holton.

All rights reserved.

This book may not be reproduced, in whole or in part, including illustrations, in any form (beyond that copying permitted by Sections Io7 and Io8 of the U.S. Copyright Law and except by reviewers for the public press), without written permission from the publishers.

Yale University Press books may be purchased in quantity for educational, business, or promotional use. For information, please e-mail sales.press@yale .edu (U.S. office) or sales@yaleup.co.uk (U.K. office).

Set in Janson Oldstyle type by Newgen North America. Printed in the United States of America.

Library of Congress Control Number: 2015955618 ISBN: 978-0-300-20762-o (cloth : alk. paper)

A catalogue record for this book is available from the British Library.

This paper meets the requirements of ANSI/NISO Z39.48-1992 (Permanence of Paper).

10 98765432 I 
This book is dedicated to all displaced persons

whose hearts continue to long for a place called home.

\author{
In Memory \\ Betty Ann Holton
}


This page intentionally left blank 